УДК 378.026.016:004

\title{
НАТАЛІЯ КОНОНЕЦ
}

Вищий навчальний заклад Укоопспілки «Полтавський університет економіки і торгівлі»,

\section{КОНЦЕПЦІЯ РЕСУРСНО-ОРІЄНТОВАНОГО НАВЧАННЯ У ВИЩІЙ ШКОЛІ}

У статті на основі аналізу теоретичної літератури та власного практичного досвіду схарактеризовано концепцію ресурсно-орієнтованого навчання у вищій школі. Авторська концепція відображає поняття, мету, суть, завдання, принципи, перспективні завдання та основні напрями розвитку ресурсно-орієнтованого навчання студентів у закладах вищої освіти. Концепція включає три взаємопов'язані концепти, які сприяють реалізації провідної ідеї дослідження: методологічний, теоретичний та технологічний.

Ключові слова: ресурсно-орієнтоване навчання, концепція, вища школа, мета, завдання, принципи

Постановка проблеми. Педагоги багатьох країн світу стурбовані тим, що сучасний зміст освіти, методи його засвоєння малопродуктивні та недостатньо задовольняють потребу студента в особистісному використанні знань як під час навчання, так і після закінчення навчального закладу, у житті, у професійній діяльності. Тому пошуки педагогів спрямовані до продуктивної освіти, в якій мірою продукту стає студент зі своїми інтересами, досвідом і освітніми цілями. Ці завдання можливо вирішити, використовуючи ресурсно-орієнтоване навчання (resource-based learning, або RBL), яке уже давно впроваджується в освітніх системах таких країн світу як Австралія, Австрія, Великобританія, Ірландія, Канада, Китай, Німеччина, Норвегія, Сінгапур, США, Тайвань, Швеція, Швейцарія, Фінляндія тощо (Кононец, 2018).

Аналіз останніх досліджень. Проблематику ресурсно-орієнтованого навчання (РОН) грунтовно досліджують зарубіжні учені М. Аньйорен, М. Батлер, М. Белл, Н. Бесвік, К. Бішоф, К. Богнер, К. Віліед, К. Войчік, М. Ганафін, Д. Гіл, К. Грінхау, Ш. Гріффіт, Дж. Девіс, С. Декстер, Р. Дойрон, Д. Доміці, Л. Кемпбелл, А. Палівала, Ж. Сміт-Отард, С. Хаджерут, Ш. Н. Чан, А. Штайнакер (та інші науковці, які однозначно надають великої ваги РОН та вбачають перспективу розширення освітніх можливостей за умови повномасштабного переходу навчальних закладів до РОН. Утім проблема організації РОН у вітчизняних закладах вищої освіти (3В0) потребує розробки відповідної концепції.

Мета статті - схарактеризувати концепцію ресурсно-орієнтованого навчання у вищій школі.

Виклад основного матеріалу. У науково-педагогічній літературі наукова концепція визначається як форма тлумачення основної ідеї теорії, як система поглядів на певне явище, спосіб його розуміння i розкривається через наукові поняття, характеристики, погляди, параметри щодо об'єкта (або фрагмента) дійсності. У нашому дослідженні концептуалізація постає як спосіб організації інтелектуальної роботи, спрямованої на відображення уявлень про РОН у вищій школі. 3 огляду на вище викладене, авторська концепція РОН студентів у ЗВО відображає поняття, мету, суть, завдання, принципи, перспективні завдання та основні напрями розвитку РОН студентів у ЗВО.

Імпонує позиція В.Громового, який наголошує, що нині тільки та система освіти може займати лідерські позиції у світі, яка: вчить студентів "як думати", а не "що думати"; забезпечує їм "рівні можливості", а не рівність; допомагає опанувати ще не існуючі знання, а не змушує зазубрювати "вчорашні"; визначає стратегію підготовки студентів до професій, які ще не існують, використовуючи методики та технології, які ще не відкрито, щоб вирішувати проблеми, про існування яких ми ще навіть не здогадуємось [0]. Концепція РОН у вищій школі (далі - Концепція) покликана втілити саме ці постулати.

Концепція грунтується на зарубіжному досвіді впровадження РОН, основних положеннях Концепції Національної програми інформатизації України, Концепції розвитку неперервної педагогічної освіти, Стратегії інноваційного розвитку України на 2010-2020 роки в умовах глобалізаційних викликів, Закону України про вищу освіту (2014р.).

Мета Концепції - озброїти систему вітчизняної вищої освіти інструментарієм упровадження РОН студентів у 3ВО. Ї̈̈ провідною ідеєю є положення про те, що якість процесу навчання у ЗВО істотно залежить від впровадження РОН. Це вимагає розроблення моделі РОН у процесі підготовки фахівців у вищій школі.

Концепція включає три взаємопов'язані концепти, які сприяють реалізації провідної ідеї дослідження: методологічний, теоретичний та технологічний.

Методологічний концепт відображає взаємозв'язок і взаємодію різних підходів загальнонаукової та конкретно-наукової методології до вивчення проблеми впровадження РОН студентів у ЗВО, а саме:

- ресурсний підхід дозволяє зосередитися на питаннях організації навчання, зорієнтованого на виявлення і розвиток потенційних можливостей кожного студента; вивчення внутрішніх ресурсів особистості та виявлення шляхів їх розкриття й реалізації в різних видах діяльності відповідно до їі природних нахилів (Ю. Ібрагім, В. Лозова, О. Малихін, С. Микитюк, Л. Суховірська); 
- акмеологічний підхід (педагогіка успіху) акумулює сукупність принципів, методів, прийомів, засобів організації і побудови теоретичної та практичної діяльності, орієнтованих на прогноз якісного результату в освіті, високий рівень продуктивності й професійної зрілості майбутнього фахівця (В. Громовий, Г. Данилова, С. Клепко);

- студентоцентрований підхід забезпечує навчальну автономію, тобто самоогранізоване навчання, самопідготовку та індивідуальну систему незалежного навчання, у центрі якого знаходиться студент; обумовлює головну ідею РОН - створити комфортні умови для навчання кожного студента (М. Ануфрієв, М. Макарова, Н. Бесвік, М. Батлер, С. Кокс, Л. Моран);

- компетентнісний підхід забезпечує спрямованість навчального процесу на розвиток у студентів ключових, предметних, професійних компетентностей, на формування умінь оперувати такими технологіями та знаннями, що задовольнять потреби інформаційного суспільства, підготують їх до нових ролей у цьому суспільстві (С. Єрмакова, О. Овчарук, В. Олійник, О. Савченко, Д. Рушен);

- системний підхід сприяє цілісному погляду на проблеми РОН у вищій школі і дозволяє розглядати його, по-перше, як інваріантний етап неперервної освіти, що здійснюється під час навчання студентів у ЗВо, по-друге, - забезпечити єдність і цілісність усіх складових компонентів змісту та процесу навчання (А. Береза, Б. Ломов, М. Рогоза, В. Сімонов, М. Вебстер);

- проектний підхід орієнтований на виконання завдань розвитку, перетворення, удосконалення РОН як сучасного освітнього процесу і базується на практико-орієнтованій діяльності, використанні сукупності матеріально-технічних, навчально-методичних, фінансових, інформаційних ресурсів і управлінських рішень щодо їх виконання (О. Бартків, М. Гриньова, Н. Сас, С. Сисоєва).

Теоретичний концепт визначає систему ідей, концепцій, вихідних категорій, основних понять, без яких неможливе розуміння суті досліджуваної проблеми: наукові дослідження у царині педагогічних технологій; інформатизації та інформаційних технологій в освіті; освітнього моніторингу; дослідження теоретичних та практичних аспектів дистанційного навчання та Інтернет-освіти; дослідження наукових підходів до методики навчання професійно-орієнтованих дисциплін; основні положення теорії інформаційних систем та економічної кібернетики; дослідження теоретичних та практичних підходів до проектування інформаційно-освітнього середовища; основні положення теорії та практики розроблення електронних освітніх ресурсів; дослідження педагогічних аспектів застосування кайдзен-технології у навчальному процесі; основних положень концепції smart-освіти, лін-освіти, педагогіки свободи.

Технологічний концепт передбачає розробку та впровадження технологічного забезпечення організації РОН у вищій школі.

\section{Основні положення}

Ресурсно-орієнтоване навчання (РОН) у вищій школі - це цілісний динамічний процес організації і стимулювання самостійної пізнавальної діяльності студентів 3 оволодіння навичками активного перетворення інформаційного середовища, який передбачає оптимальне використання тріадою "студентвикладач-бібліотекар" консолідованих кадрових, матеріально-технічних, навчально-методичних, фінансових та інформаційних ресурсів.

У Концепції під ресурсом розуміється все те, що може бути використане для забезпечення функціонування й розвитку ЗВО та процесу РОН зокрема.

Зовнішні ресурси поділяються на: кадрові (науково-педагогічні, педагогічні кадри, адміністрація, працівники бібліотеки, технічний персонал тощо); навчально-методичні (традиційні та електронні ресурси); матеріально-технічні (приміщення, обладнання, бібліотечний фонд, програмне забезпечення); фінансові ресурси (кошти, які перебувають у розпорядженні 3 ВО і призначені для виконання ними певних фінансових зобов'язань); інформаційні ресурси (сукупність документів в інформаційних системах) (Прокопенко, 2013; Сас, 2015).

Зовнішні ресурси складають кампус ЗВо - інфраструктуру 3В0, яка включає в себе будівлі, аудиторії, лабораторії, бібліотеки, гуртожитки, їдальні, спортивні зали тощо.

Внутрішні ресурси розглядаємо як суб'єктивні можливості студента, викладача та бібліотекаря (як ті, що $є$ в наявності, так і ті, що являють собою потенціал для розвитку й удосконалення), які завдяки різним зусиллям можуть стати необхідними й актуалізованими у процесі РОН (Кононец, 2016).

Мета POH у вищій школі: інформаційна компетентність, інформаційна культура студента як майбутнього конкурентноспроможного фахівця, професійна компетентність для успішної життєдіяльності в інформаційному суспільстві, зорієнтованість на освіту упродовж усього життя.

РОН у вищій школі спрямоване на вирішення низки завдань:

- забезпечення партнерства викладача та студентів, під час якого здійснюється стимулювання та організація активної самостійної пізнавальної діяльності студентів з метою набуття компетентностей, окреслених у змісті навчання кожної конкретної дисципліни;

- формування у студентів умінь формулювати мету навчальної діяльності, моделювати й проектувати власну навчальну діяльність; розвиток прагнення домагатися реалізації мети; формування умінь оцінювати та аналізувати результати навчальної діяльності;

- формування у студентів умінь використання прийомів пошуку інформації за допомогою широкого спектру інформаційних ресурсів та їі обробки; навчити їх самостійно здобувати, оновлювати, поповнювати знання, аналізувати та використовувати їх під час навчання та в подальшій професійній діяльності будувати знання, досліджувати їх та приймати рішення; 
- розвиток плідної співпраці тріади "студент-викладач-бібліотекар" як інноваційної форми взаємодії, за якої викладач та бібліотекар допомагає студентові навчатися самостійно (Біла книга, 2009; Гриньова, 2008).

Суть РОН у вищій школі: студент - дослідник інформаційного середовища (explorer), викладач тьютор (tutor), бібліотекар - педагог-бібліотекар (teacher-librarian).

Принципи РОН у вищій школі:

1. Принцип універсальності полягає у тому, що РОН здатне оптимально реалізувати всі загальновідомі дидактичні принципи (науковості; природовідповідності; наочності; зв'язку навчання 3 життям; інтерактивності; свідомості й активності; диференціації; емоційності навчання; цілеспрямованості й цілісності навчання; оптимізації; формування в студентів пізнавального інтересу; контролю і корекції знань студентів; систематичності і послідовності; поєднання освіти і самоосвіти, розвитку і саморозвитку, виховання і самовиховання тощо).

2. Принцип самостійності та керованості при РОН полягає у тому, що студент самостійно керує власною навчальною діяльністю, при цьому має можливість використовувати будь-які зручні і доступні для себе інформаційні ресурси, а також перевіряє себе, обираючи відповідні своїм уподобанням методи контролю (тести, метод портфоліо тощо) та завдання відповідного рівня складності. Цей принцип обумовлює ефективне керування всіма ресурсами - забезпечення постійного вдосконалення та поліпшення процесу навчання за допомогою внутрішніх резервів та без залучення додаткових фінансових коштів.

3. Принцип свободи вибору полягає у свідомому виборі необхідної і бажаної мети як відображення можливостей у свідомості студента, передбачення тенденцій майбутнього, їхнє оцінювання 3 позицій інтересів студента, висунення однієї з можливостей як ідеального образу - мети. Він враховує той факт, що свобода $\epsilon$ необхідною умовою самореалізації особистості студента, формування його самостійної пізнавальної діяльності, оскільки вона сприяє індивідуалізації життєвого світу студента. Думка про свободу вибору породжує у студента почуття відповідальності, примушує його зважати на наслідки своїх вчинків, дивитися на себе очами інших, брати відповідальність за своє навчання на себе.

4. Принцип саморегуляції полягає у використанні студентом різних засобів навчання, які сприятимуть оволодінню засобами виконання навчальних операцій таким чином, що будь-яка зміна умов завдання, зустріч з ускладненням спричиняла включення таких механізмів мислення, які призводять до самостійного розв'язку завдання чи проблеми. Цей принцип $\epsilon$ орієнтацією студента на те, щоб вони завжди налаштовували себе на успіх: у навчанні, у житті, у майбутній професійній діяльності.

5. Принцип неперервності випливає з того, що РОН є багатогранним і багатофакторним процесом, який не обмежується в часі, просторі та методах навчання, віковими межами; РОН здійснюється з часу навчання в ЗВО і орієнтує студента на освіту упродовж усього життя. Базується на концептуальних засадах неперервної освіти та забезпечує неперервне врахування індивідуальних особливостей студентів через використання ІКТ та мережних технологій.

6. Принцип індивідуалізації забезпечує побудову індивідуальної освітньої траєкторії (персональний шлях реалізації особистісного потенціалу кожного студента чи викладача в освіті). За цим принципом кожному студентові надається можливість іти до оволодіння навчальним матеріалом своїм шляхом вибудовувати індивідуальну траєкторію навчання. Викладач у свою чергу має можливість, враховуючи здібності, інтереси, темп навчання окремого студента, їх розумового та вольового розвитку, рівень компетентностей, працездатності, самостійної пізнавальної діяльності та практичної самостійності студентів, їх ставлення до навчання, вибудовувати індивідуальну траєкторію викладання дисципліни.

7. Принцип інтернаціоналізації полягає у можливостях експорту й імпорту світових досягнень педагогічної теорії й практики на сучасному ринку освітніх послуг; забезпечує мобільність студентів і викладачів; можливість використання різноманітних електронних освітніх ресурсів, формування відкритого навчального середовища завдяки доступності Інтернету та сучасних IКТ.

8. Принцип доступності базується на загальновідомому дидактичному принципі та підсилюється принципом леза (бритви) Оккама - методологічним принципом, який вимагає усунення з науки всіх понять, які не $\epsilon$ інтуїтивно очевидними та які не підлягають перевірці в досвіді: "Сутності не слід примножувати без необхідності".

9. Принцип раціоналізації базується на принципі KISS (keep it short and simple) - роби коротше та простіше: 1) Чим простіша модель РОН, тим вона краща, тим легше ії впроваджувати; 2) Розробка електронних освітніх ресурсів та засобів навчання для якісної організації освітнього процесу за допомогою доступного й простого програмного забезпечення; 3) Використання раціональних прийомів пошуку інформації: вдосконалення, покращення процесу побудови знань.

10. Принцип інформаційного підходу базується на тому, що сьогодні інформація є головним ресурсом науково-технічного та соціально-економічного розвитку, істотно впливає на прискорений розвиток науки, техніки і різних галузей господарства, відіграє значну роль у процесах освіти, культурного спілкування між людьми, а також в інших соціальних областях; процес навчання є насамперед особливим, закріпленим у культурі способом оперування інформацією.

Перспективні завдання РОН у вищій школі

1. Мобільність процесу РОН у вищій школі повинна стати реальністю (створення інформаційних мереж, баз і банків знань та даних для дистанційної форми навчання зі збереженням інформаційної інваріантної освіти). 
2. Системна організація розробки електронних освітніх ресурсів та їх впровадження повинна враховувати те, що ці ресурси мають бути доступні з кожного мобільного пристрою (Кононец, Гриньова, 2018).

3. Розширене та умотивоване використання електронних освітніх ресурсів повинно стати необхідністю у процесі підготовки фахівців у вищій школі.

4. Переорієнтація процесу навчання через залучення бібліотекарів до навчального процесу в 3 ВО має здійснюватися на основі педагогіки партнерства, що сприяє плідній, ефективній співпраці тріади "студентвикладач-бібліотекар".

5. Трансформація бібліотеки в конструкцію "бібліотека + лабораторія" має здійснюватися за допомогою комп'ютеризації приміщень бібліотеки засобами комп'ютерної техніки та підключення до мережі Інтернет, Wi-Fi. Бібліотека має стати інформаційним центром 3BO.

6. Побудова ефективної системи підвищення кваліфікації науково-педагогічних, педагогічних кадрів та бібліотекарів для ширшого застосування РОН має здійснюватися за допомогою проведення спільних засідань, семінарів-практикумів, майстер-класів, вебінарів, виставок, педагогічних панорам тощо.

7. Розробка ефективного механізму залучення студентів до відвідування бібліотек та використання електронних бібліотек має здійснюватися на основі тісної співпраці з бібліотеками ЗВО та місцевими громадськими бібліотеками: відвідування різноманітних заходів, які проводять бібліотеки, активна участь студентів в організації таких заходів, волонтерство тощо.

8. Розвиток співпраці з різними ЗВО та освітніми установами має здійснюватися для забезпечення відкритості освітнього процесу, ступеня ï інтеграції в європейську і світову освітні системи, що сприяє об'єктивізації оцінювання рівня роботи 3В0, активному використанню найкращого світового досвіду.

9. Розширення взаємодії 3ВО через мережеве співробітництво має забезпечувати підвищення якості й доступності освітніх програм та ресурсів за рахунок залучення і використання у мережі кадрових, матеріально-технічних, інформаційних, навчально-методичних, фінансових та інших ресурсів, які недоступні в інших умовах.

10. Реалізація сучасних технологій обміну досвідом між науково-педагогічними працівниками має сприяти поширенню досвіду РОН через організацію і проведення спільних круглих столів, семінаріваукціонів, вебінарів, форумів, конференцій, Інтернет-конференцій, тренінгів, майстер-класів тощо.

11. Подальше вдосконалення дидактичних умов реалізації РОН має здійснюватися постійно, оскільки варто враховувати усе нове, що створюється людством у галузі ІКТ та педагогічної практики. Варто враховувати, що РОН є вектором у розвитку неперервної освіти, smart-освіти та лін-освіти.

12. Оновлення змісту, засобів, методів, форм, педагогічних технологій РОН має здійснюватися 3 урахуванням вітчизняних стандартів освітньої діяльності, міжнародної інтеграції та інтеграції системи освіти України у світовий освітній простір за умови збереження і розвитку досягнень та прогресивних традицій української вищої школи.

13. Створення оптимальних умов для втілення через РОН парадигми "освіта упродовж усього життя" має стати підгрунтям для майбутнього професійного самовдосконалення та самореалізації кожного студента, який працюватиме на благо України.

14. "ЗВО - це я". Поняття "ЗВО" не повинно асоціюватися 3 приміщенням, це перш за все стиль викладання, спосіб організації нової освітньої реальності - індивідуальної освітньої програми. Будь-який ЗВО має створити всі можливі передумови для того, щоб кожен студент мав підстави сказати: "ЗВО - це я".

Основні напрями розвитку РОН у вищій школі

1. Вдосконалення форм, методів, засобів, педагогічних технологій РОН у вищій школі.

2. Розробка та вдосконалення науково-методичного забезпечення процесу організації РОН у вищій школі (наукові публікації, монографії, навчально-методичні посібники тощо).

3. Розробка та впровадження у процес підготовки фахівців у вищій школі електронних освітніх ресурсів.

4. Співпраця з різними ЗВО, освітніми установами, бібліотеками та мережеве співробітництво.

Таким чином, запропонована концепція сприятиме реформуванню сучасної мережі освітніх закладів із тим, щоб вона відповідала потребам економіки регіонів, інтеграції освіти й науки та інноваційним технологіям навчання. Безперечно, РОН забезпечить удосконалення освітнього процесу в 3 ВО 3 урахуванням сучасних IКТ, доступність та ефективність освіти, підготовку молодого покоління до життєдіяльності в інформаційному суспільстві.

Висновки. Підбиваючи підсумки, зазначимо, що реалізація концепції РОН у вищій школі забезпечить: якісно новий рівень організації освітнього процесу в 3В0; високий рівень сформованості самостійної пізнавальної діяльності у студентів; високий рівень професійної компетентності випускників для успішного здійснення професійної діяльності в умовах життя в інформаційному суспільстві; чітку орієнтацію студентів на самостійне здобування знань та уміння будувати знання; чітку орієнтацію студентів на освіту упродовж усього життя; підвищення ефективності РОН за умови використання засобів, методів, форм та педагогічних технологій РОН; формування спільного відкритого навчального середовища 3В0; співпрацю з різними 3В0, освітніми установами, бібліотеками та дисемінацію педагогічного досвіду РОН; розвиток мережевого співробітництва ЗВО. 


\section{Список використаних джерел}

Біла книга (Сили змін та вектори руху до нової освіти України). (2009). / упоряд. В. Громовий. Київ : Міжнародний благодійний фонд "Україна -3000". 156 с.

Гриньова, М. В. (2008). Саморегуляиія : навч.-метод. посіб. Полтава : АСМI. 268 с.

Кононец, Н.В. (2018). Функціональна дидактична модель ресурсно-орієнтованого навчання дисциплін комп'ютерного циклу у вищій школі. Social and Economic Aspects of Education in Modern Society. (38-41). Vol.2. Warsaw, Poland. C. 38-41.

Кононец, Н.В., Гриньова, М.В. (2018). Засоби створення електронного посібника для ресурсно-орієнтованого навчання. Проблеми сучасного підручника : зб. наук. пращь. Топузов, О. М. (Гол. ред.). К.: Педагогічна думка. Вип. 20. С. 166-179.

Кононец, Н. В. (2016). Дидактичні основи ресурсно-орієнтованого навчання дисциплін комп'ютерного циклу студентів аграрних коледжів. (Дис. докт. пед. наук). Полтава. $473 \mathrm{c.}$

Прокопенко, І. Ф. (2013). Розвиток і модернізація ринку послуг вищої освіти в Україні. Збірник наукових пращь Харківського нац. пед. ун-ту імені Г. С. Сковороди. "Економіка". Вип. 13, 5-14.

Сас, Н. М. (2015). Тенденції професійної підготовки майбутніх керівників навчальних закладів до інноваційного управління (теоретико-методологічний аспект). (Дис. ... докт. пед. наук). Черкаси.

\section{References}

Bila knyha (Syly zmin ta vektory rukhu do novoi osvity Ukrainy). (2009). / uporiad. V. Hromovyi. Kyiv : Mizhnarodnyi blahodiinyi fond "Ukraina-3000".

Hrynova, M. V. (2008). Samorehuliatsiia : navch.-metod. posib. Poltava : ASMI.

Kononets, N.V. (2018). Funktsionalna dydaktychna model resursno-oriientovanoho navchannia dystsyplin kompiuternoho tsyklu u vyshchii shkoli. Social and Economic Aspects of Education in Modern Society. (38-41). Vol.2. Warsaw, Poland.

Kononets, N.V., Hrynova, M.V. (2018). Zasoby stvorennia elektronnoho posibnyka dlia resursno-oriientovanoho navchannia. Problemy suchasnoho pidruchnyka : zb. nauk. prats. (166-179). Holov. red. O.M. Topuzov. K.: Pedahohichna dumka. Vyp. 20.

Kononets, N. V. (2016). Dydaktychni osnovy resursno-oriientovanoho navchannia dystsyplin kompiuternoho tsyklu studentiv ahrarnykh koledzhiv. (Dys. dokt. ped. nauk). Poltava. $473 \mathrm{~s}$.

Prokopenko, I. F. (2013). Rozvytok i modernizatsiia rynku posluh vyshchoi osvity v Ukraini. Zbirnyk naukovykh prats Kharkivskoho nats. ped. un-tu imeni H. S. Skovorody. "Ekonomika". Vyp. 13, 5-14.

Sas N. M. (2015). Tendentsii profesiinoi pidhotovky maibutnikh kerivnykiv navchalnykh zakladiv do innovatsiinoho upravlinnia (teoretyko-metodolohichnyi aspekt). (Dys. dokt. ped. nauk). Cherkasy.

\section{KONONETS N.}

University of Ukoopspilks "Poltava University of Economics and Trade", Ukraine

\section{THE CONCEPT OF RESOURCE-BASED LEARNING IN HIGHER SCHOOL}

In the article, based on the analysis of theoretical literature and own practical experience, the concept of resourceoriented learning in the high school is described. The author concept reflects the concept, purpose, essence, task, principles, perspective tasks and the main directions of development of resource-oriented teaching of students in institutions of higher education. The concept includes three interconnected concepts that contribute to the implementation of the leading idea of research: methodological, theoretical and technological.

It is grounded that the implementation of the concept of RHE in higher education will ensure: a qualitatively new level of organization of the educational process in the ZOO; high level of formation of independent cognitive activity among students; a high level of professional competence of graduates for the successful realization of professional activity in a living environment in the information society; a clear orientation of students for independent acquisition of knowledge and ability to build knowledge; a clear orientation of students for education throughout their lives; increasing the effectiveness of RHO provided the use of facilities, methods, forms and pedagogical technologies RON; formation of a joint open educational environment of the ZOO; cooperation with various ZOO, educational institutions, libraries and dissemination of pedagogical experience of RON; development of network cooperation ZOO.

Key words: resource-based learning, concept, higher school, purpose, tasks, principles

Стаття надійшла до редакції 04.11. 2018 р. 